\title{
Study on the Marketing Value of International Fashion Shows
}

\author{
A Case Study of Bosideng's Debut at New York Fashion Week
}

Jiangyun $\mathrm{Yu}^{1,{ }^{*}}$ Hongzhong Shan ${ }^{1}$

${ }^{1}$ School of Business, Beijing Institute of Fashion Technology, Beijing, China

*Corresponding author.Email:shz0306@sina.com

\begin{abstract}
Bosideng, a well-known China brand, first boarded New York Fashion week on September 11, 2018. The use of international fashion week marketing has a high marketing value, which indirectly promoted the sales growth of Bosideng down garment. Based on the analysis and judgment of marketing value, this paper analyzes the effect of international fashion show on the marketing value of enterprises, and finally puts forward countermeasures and suggestions on the promotion of fashion show marketing to revenue growth.
\end{abstract}

\section{Keywords: international fashion show, marketing value, Bosideng}

\section{INTRODUCTION}

Kotler believes that value creation includes two aspects: product value and intangible value. Product value includes product attribute and product, differentiated quality, etc. Intangible value includes a series of creation methods. Zhang Wenjian (2008) believes that marketing value refers to customer value, which is the joint effect of various attributes of an enterprise and its products (services), and can bring the final increase in benefits to customers as assessed. ${ }^{1} \mathrm{Li}$ Lian (2006) believes that marketing value includes 3 elements, i.e. brand, service and process. Its goal is to win the share of the target market and ultimately bring a win-win situation for enterprises and consumers. Li Jian (2018) believes that under the traditional management perspective, the enterprise value is mainly reflected by financial value indicators, which can systematically reflect the impact of marketing on the enterprise financial value on the financial statements of the enterprise and clearly reflect the cost and income of the enterprise. However, Marketing Assets such as brand Assets and customer assets formed by establishing good relationship with customers are difficult to reflect. However, in practice, except for the sales growth which can be reflected by the price, other items are not very intuitive, and it is difficult to directly quantify. Therefore, in this paper, marketing value is defined as two parts, tangible and intangible, including sales,

Zhang Wenjian, Fan Hui. An Exploration of the Customer Value in the Travel Agency Marketing[J]. Journal of East China Normal University (Philosophy and Social Sciences), 2003(02):107$112+125$ financial value of sales growth and brand assets, potential customers, brand loyalty, etc.

\section{ANALYSIS ON THE MARKETING FEATURES AND CURRENT SITUATION OF INTERNATIONAL FASHION SHOWS}

\section{A. The historical development of fashion shows}

According to the Chinese Travel Encyclopedia, fashion show is a kind of performance activity for fashion models to show their clothes, accessories and other things in front of the audience through stage walking and other actions in a specific venue. In the modern fashion industry structure, fashion show is an increasingly important part, which is closely related to fashion design, production and sales, and also affects the development of the entire fashion industry. With the continuous development of economy and society, fashion shows have also become an important way of international marketing. In particular, some domestic enterprises hope to use fashion shows to stand out in the international market, attract attention and expand influence.

The emergence of fashion can be traced back to the mature period of industrial society and the development of the asset class. At first, fashion stores are the means used to promote products, which have the function of promoting fashion products and conveying the designer's concept. Fashion show is a new branch of performance which gradually rises with the advancement of industrial revolution. Firstly, it aims to break through the window restrictions and act as a display of active racks, and then evolved into a performance activity to show the creative intention of 
fashion designers and the art of clothing. Through the display of models in fashion shows, fashion companies, distributors, agents, fashion media, consumers and other people have a certain understanding of the creative style of designers, and have a cognition of fashion products, thus leading to consumption and even changes in concepts. In addition, modern fashion shows also release the latest fashion trends, fabrics, colors and other functions.

\section{B. Marketing features of international fashion shows}

1) Highly centralized information: International fashion show can be said to be a carrier with highly centralized information in a certain time and space. It not only includes the displayed fashion, but also includes the exhibitors and consumers from all over the world, as well as industry information such as new technologies and new ideas. The concentrated holding of fashion week has gathered a large number of supply and demand information and fashion information in a short period of time, which brings great convenience to both the exhibitors and buyers. Brand exhibitors can release the trend information of the new season and maximize brand promotion in the time of customer concentration. Fashion buyers can participate in the shows and order fairs in a concentrated manner, and also provide convenience for the exhibitors and customers. It is a convenient place for negotiation and avoids the problem of insufficient orders due to time constraints.

2) Large space for transaction selection: International fashion shows provide a wide selection space for traders. Faced with a large number of product suppliers, buyers can have enough time to choose between the fashion and services provided by major brand suppliers, and can compare between the preferred suppliers, select one that is equal in fashion itself, price and quality, and then place an order, which greatly reduces the information asymmetry between brand manufacturers and consumers, which may facilitate the buyer to choose a better trading behavior.

3) Great reflection of the industry frontier: The international fashion show is a professional fashion release platform in the fashion industry. The holding of fashion week shows the fashion hot-spots of the new season carefully planned by major influential brands within half a year. The participation of major representative brands can effectively reflect the cuttingedge trends of the fashion industry.

4) Specific art modes: During the international fashion shows, apparel enterprises often make use of sound, light, electricity and other technologies, combined with the characteristics of their own brands to create a show stage that matches the brand characteristics, so as to increase the audience's attention to their fashion brands. Artistic forms of expression will also promote the cooperation between professional customers and brands, and help the good development of the brand in the future.

5) Combinations with exhibitions, conferences and various special events: At present, the international fashion show has gradually developed into a comprehensive industry platform. In order to enhance the attraction of fashion week to exhibitors and professional audiences, major brands will also hold static fashion shows, product exchanges and orders trade fair, personal speech of famous designers, design exchange conference, fashion party and other professional activities matching the development of fashion week to strengthen the overall effect of fashion week. On the other hand, exhibitions, conferences and various special activities have greatly enriched the content of fashion week, and can also improve the quality of fashion week, expand the popularity of fashion week and attract the attention of the media.

\section{Overview of international fashion shows}

Currently, there are four famous international fashion weeks in the world, including Paris fashion week, New York fashion week, Milan fashion week and London Fashion week. The development status of the world's four major international fashion week is shown in "Table I". These fashion weeks have different positioning and styles, but they have attracted outstanding fashion enterprises, designers and fashion buyers from all over the world. In addition to the four major fashion weeks, there are various fashion weeks around the world, such as Los Angeles fashion week, Tokyo fashion week, Seoul fashion week, Copenhagen fashion week, Shanghai fashion week, Shenzhen fashion week and Harbin fashion week. 
TABLE I. DEVELOPMENT STATUS OF FOUR MAJOR INTERNATIONAL FASHION WEEK

\begin{tabular}{|c|l|l|l|l|}
\hline Fashion Week & Country & Establish time & Hosting frequency & \multicolumn{1}{c|}{ Location } \\
\hline Paris fashion week & France & 1973 & Twice a year & Advanced customization, ladies' wear \\
\hline New York fashion week & The US & 1943 & Twice a year & Leisure and sports equipment \\
\hline Milan fashion week & Italy & 1967 & Twice a year & Men's wear, advanced garments \\
\hline London Fashion week & England & 1983 & Twice a year & Men's wear \\
\hline
\end{tabular}

\section{THE ANALYSIS OF THE INFLUENCE OF NEW YORK FASHION WEEK ON BOSIDENG}

\section{A. The background of down garment}

In 2018, the growth rate of China's GDP and income showed a slowdown trend, the market consumption was weak, and the textile and apparel industry also showed a downward trend. In terms of output, in recent years, the output of down garments in China has shown a downward trend. In 2018, the output of down garments in China was 195 million 898 thousand units, representing a year-on-year decrease of 5.4\%. (See "Fig. 1")

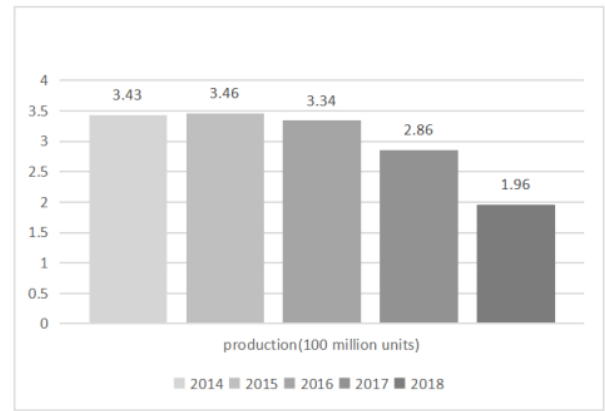

Fig. 1. The production of China down garment market.

From the perspective of market size, the overall down garment market in China is improving, showing an upward trend of recovery. According to the statistics of China Apparel Association, as of 2017, the market size of down garments in China has reached 96 billion 350 million yuan, representing a year-on-year increase of $12.4 \%$. In 2018, the size of China's down garment Market increased to 106 billion 820 million yuan, maintaining a growth rate of more than $10 \%$. It is predicted that the market size of down garments in China will approach 120 billion yuan in 2019, with a year-on-year increase of $10.7 \%$. In addition, the current penetration rate of down garments in China is only about $10 \%$, and there is still a lot of room for development in the future. (See "Fig. 2")

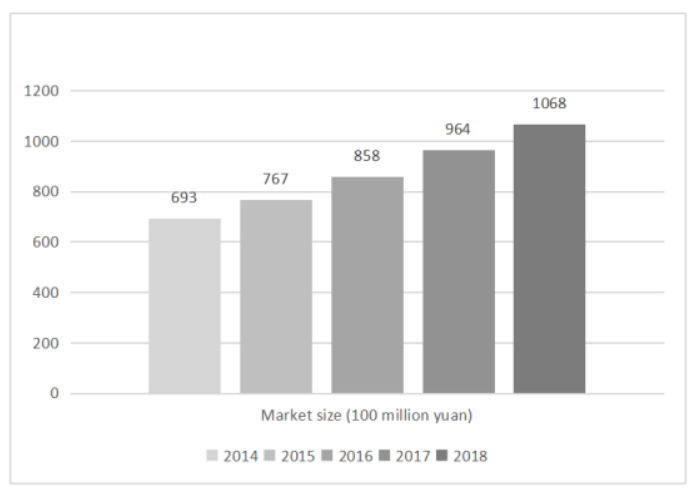

Fig. 2. The size of China down garment market.

In terms of price, the price of down garments has increased to different degrees since 2017.The price of down garments increased with the increase of duck down price, processing cost and logistics cost. In addition, the industry leaders boosted the momentum, especially the active price increase of Bosideng, which is positioned as a mid - to high-end product, and the influx of foreign brands such as Canada geese into China in the past two years. (See "Fig. 3")

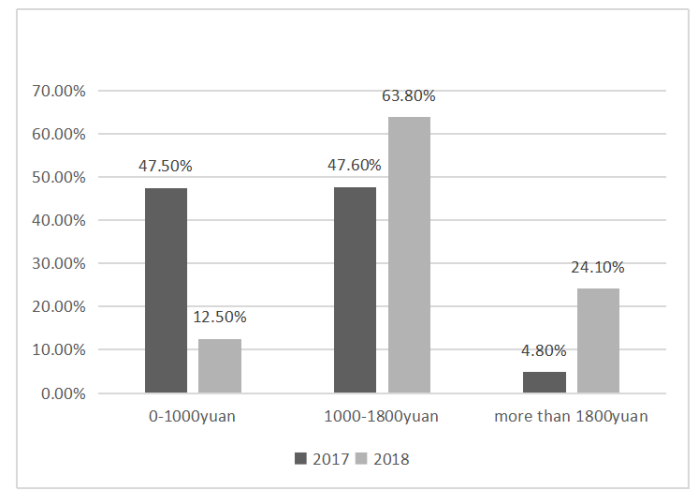

Fig. 3. The price of China down garment market.

The industry competition pattern is constantly changing, and domestic consumers pay more attention to quality and fashion sense. At the same time, foreign professional down garment brands and four seasons down garment brands are seizing the market share in China. In the context of consumption upgrading, the audience pays more attention to quality and fashion sense, resulting in the dual pressure of product and brand strength on traditional down garment brands. 


\section{B. Analysis on the current situation of Bosideng}

Founded in 1976, Bosideng has 43 years of down garment $\mathrm{R} \& \mathrm{D}$, design and production history, and has been the first in sales volume in China for 23 consecutive years. As a leader in Chinese down garments, Bosideng has been entering the international market since 1995, and has been well sold in 72 countries around the world, such as the United States, Italy, etc.

However, with the deepening of globalization, Bosideng also faces many threats. Firstly, due to the aging of its own brand, the positioning of target customers is not clear and young people are not interested in it, while the "aging" of mainstream customers leads to consumption dislocation. Secondly, although Bosideng is cost-effective, the sales volume of other brands, especially international brands such as "Canadian goose", has been declining in recent years. Therefore, how to increase the core competitiveness of enterprises, and then re-enter the international market, and improve sales volume and sales volume, has become the demand of Bosideng enterprise marketing.

According to the annual revenue data of Bosideng, starting from 2013, the revenue of Bosideng gradually decreased, and fell into a low point in 2016. Until 2017, the growth rate began to increase, and in 2019, the revenue successfully exceeded 10 billion, with significant increase. (See "Fig. 4")

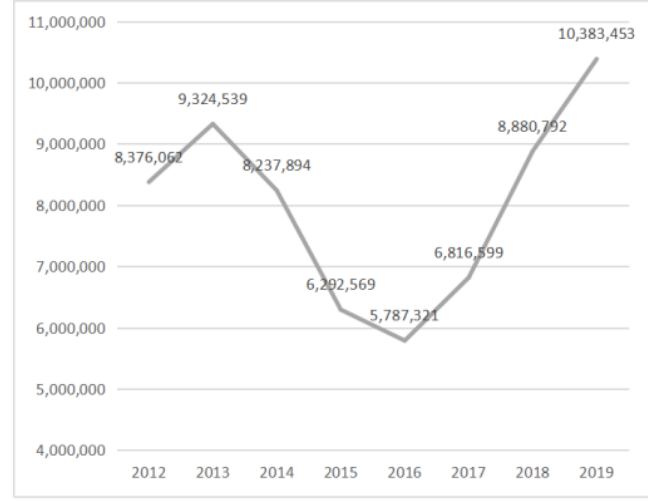

Fig. 4. The annual revenue data of Bosideng.

\section{The influence of fashion show marketing on Bosideng}

On 12 September 2018, Bosideng released a show on the theme of [皤 you] at the main venue of New York fashion week, mainly showing down clothing products, showing the use of Chinese elements and technology in clothing. The use of international fashion show marketing has brought the following aspects of influence to Bosideng.

1) Increase in potential target customers: The live broadcast of New York fashion week attracted more than 3 million 90 thousand people to watch by appointment, 1 million 200 thousand people to watch online, and $85 \%$ of the reservation was made by hard advertisement + circle of friends plus Flash advertisement. In terms of communication, the total number of online publicity content read, forwarded and liked by more than 200 fashion, commercial and apparel industries on micro-blog and $\mathrm{WeChat}$ reached 30 million times, 420 thousand times and 36 thousand times respectively. Today, the power and speed of social media cannot be underestimated, the outstanding performance of enterprises on fashion shows will bring a huge amount of traffic, attracting willing consumers to effectively participate in purchasing activities.

2) Large increase in operating income: By participating in the internationally renowned fashion week, enterprises can help them to explore the international market. To a certain extent, the attention gained from this marketing activity can be translated into the sales volume of products, improve product pricing, and thus increase the income of enterprises in products. Featured and displayed high-end products can update product lines and improve product profits. According to the financial report of Bosideng in 2018 and 2019 , the group's operating revenue was 10 billion 384 million, representing an increase of $16.9 \%$ over the same period of last year. Gross profit increased significantly by $33.9 \%$ to RMB 5 billion 514 million, and gross profit margin increased by 6.7 percentage points to $53.1 \%$.

It is worth noting that the revenue of down garment business was RMB 7 billion 658 million, representing an increase of $35.5 \%$ over the same period of last year. The revenue of Bosideng down garment, the main brand, increased by $38.3 \%$ over the same period of last year to RMB 6 billion 849 million. The proportion of contribution continued to increase, which was the largest engine for the development of the group.

3) Optimizing the production structure and promoting the transformation and upgrading of enterprises: The significant increase in the operating revenue of Bosiden group is inseparable from the innovation and change of its marketing strategy. Benefiting from the steady development of the core down garment business and seizing the market opportunities for consumption upgrading, the main business of Bosideng group has boosted Bosideng's recognition and brand strength among consumers, and driven the stable rise of the brand down garment business and the group's total revenue.

The main revenue source of Bosideng consists of 4 parts, down garments, OEM processing management, women's wear and diversified clothing. Compared with 
2018, Bosideng still achieved a higher proportion in the two major businesses of down garment and OEM processing management this year, while the women's wear and diversified apparel sectors were shrinking.

4) Conveying brand design concept and improving brand awareness: Although the focus on brand concept also depends on other factors such as product quality and after-sales service, international fashion shows can create attention, strengthen product positioning and convey brand design concept. In the increasingly visual oriented culture, it is particularly important for Bosideng to interpret the significance and positioning of the brand by displaying unique design.As a functional apparel company, Bosideng's participation in fashion shows can not only convey innovative brand design concepts to consumers and fashion buyers, but also raise public awareness through fashion shows and their subsequent online marketing communications. Meanwhile, the fans effect brought by celebrities attracted by international fashion shows can also attract consumers' attention to products or brands.

\section{COUNTERMEASURES AND SUGGESTIONS FOR FASHION SHOW MARKETING TO PROMOTE THE GROWTH OF ENTERPRISE REVENUE}

\section{A. Positioning the audience's interests and using fashion shows to show their own characteristics}

In the traditional advertising marketing process, there is often a problem that the marketing content does not match the target group, which brings public relations crisis to the enterprise. It is undeniable that excellent marketing creativity based on the education level, values and personality characteristics of the target audience will indeed attract the attention of the target group. Enterprises participating in fashion shows, if it is only a simple listing of products, will make consumers lose interest and reduce people's enthusiasm for the brand. On such a platform as the international fashion show, enterprises should determine their own characteristics and advantages in participating fashion shows, show clear positioning and unique theme, grasp the platform where fashion directors, buyers, customers and enterprises are present, show their own strengths and win the attention of consumers. As a leader of down garment industry, Bosideng participated in New York fashion week, which fit the positioning of "leisure and sports equipment" and the characteristics of "business and leisure" of New York fashion week, thus attracting the attention of professionals and consumers in relevant fields.

\section{B. Value order fairs and buyers}

The ultimate goal of the upstream fashion industry, the main body of the midstream fashion week, the media, and supporting services must be attributed to the downstream consumption, so as to realize the industrial value of the fashion week. Fashion Week deals with the boring part of product ordering meeting with consumption. Fashion shows are held to attract consumers from all over the world, and ultimately for the sale of fashion. Only by converting fashion into commerce, can such operation system be complete. Enterprises should pay attention to order fairs and fashion buyers, attract consumers from all over the world, and ultimately promote the sales of products.

In addition, enterprises should also focus on other activities during the fashion week, including personal speeches of designers, fashion shows in static exhibition halls, production and sales exhibitions of clothing and fabrics and other colorful activities to support the development of fashion week.

\section{Enhancing media resources and means of publicity}

As a well-known domestic brand, the rise of Bosideng has triggered many consumer recollections. However, there are still some deficiencies in the marketing and promotion of enterprises through online media, such as the media full of articles and floating reports on the event of Bosideng's debut New York fashion week. After a successful fashion show, enterprises should also carry out more online activities related to fashion shows and enrich their participation methods, such as live broadcasting, micro-blog topics, etc., to guide people to shift their focus from the fashion show itself to the products and design of enterprises, so as to increase sales and sales.

\section{Help from apparel industry association}

Many well-known apparel industry associations and other fashion industry associations in the world can provide various services for the development of enterprises, including information consulting services, coordination services and other services, as well as the latest fashion information, the development trend of the apparel industry and the analysis of the global economic situation. Apparel enterprises can take advantage of the information provided by apparel industry associations such as the China Association of fashion designers to participate in fashion shows that are in line with their own main brands and products, and increase marketing means, which is conducive to brand building.

\section{CONCLUSION}

To sum up, the marketing of using international fashion shows has a high marketing value, which indirectly promotes the sales growth of Bosideng. And as for China's textile and clothing enterprises, the use of international fashion shows and other marketing means can effectively promote the growth of sales and popularity of the enterprises, and can also promote the internationalization of enterprises. 


\section{References}

[1] Francesco Schiavone, Michele Simoni. Strategic marketing approaches for the diffusion of innovation in highly regulated industrial markets: the value of market access [J]. The Journal of Business \& Industrial Marketing, 2019, 34(7).

[2] Kotler, Philip. Marketing Management [J]. Upper Saddle River, 2007, 17(1):99-99.

[3] Zhang Wenjian, Fan Hui. An Exploration of the Customer Value in the Travel Agency Marketing [J]. Journal of East China Normal University (Philosophy and Social Sciences), 2003(02): 107-112+125.

[4] Li Lian. Analysis of enterprise marketing value under multiple obstacles [J]. Market Modernization, 2006(10): 158-159.

[5] Zhang Jing, Yuan Hao. Research on enterprise marketing system based on marketing value chain [J]. Economic Review Journal, 2012(12): 110-113.

[6] Li Jian, Ji Chunli, Zhang Qiang. Research on Marketing Value Creation Logic and Process [J]. Management World, 2018, 34(06): 182-183.

[7] Liu Yiran. Marketing value based on Tiktok short video [J]. Marketing Management Review, 2019(04):76.

[8] Zheng Huimin. A Study on the Development of British Fashion Show [D]. Beijing Institute of Fashion Technology, 2012.

[9] Zhao Yuwen. The contrastive study of operating models between China and foreign fashion week [D].Wuhan Textile University, 2017.

[10] Investor relations\& Annual/Interim reports. http://company.Bosideng.com/gb/ir/reports.php\#2019

[11] Philip R.Cateora, Mary C. Gilly, John L. Graham. International Markecting [M]. Beijing: China Machine Press, 2012:337-339.

[12] Pan Xue, Wen Yi. A brief analysis of the brand marketing value of quadratic element [J]. Humanity Forum, 2018(00):250-257. 